Check for updates

London, UK

Cite this as: BMJ 2020;370:m3272 http://dx.doi.org/10.1136/bmj.m3272 Published: 03 September 2020

\section{The grass isn't always greener: the businessman turned ENT surgeon}

\author{
The consultant ear, nose, and throat surgeon tells Marika Davies about how a varied career path \\ led him to medicine
}

\section{Marika Davies}

As a young graduate working in the oil industry, David Walker learnt to be proactive about getting things done. "The phrase 'own the problem,' was drilled into us from day one," he says. "If there's a problem, you fix it. Don't wait for others.”

Walker had a varied career before becoming a doctor. His father was a GP, but Walker chose to complete his first degree in geology. After graduating from St Andrew's University in 1986, he travelled to Argentina to work herding livestock on a ranch, where he learnt "to see the world a bit differently."

On returning to the UK, Walker worked for Esso as an operations planner before deciding to further his studies, gaining a doctorate in geology at Edinburgh University in 1992. Over the next three years he took on a series of different roles, working as a market researcher for Procter and Gamble, a grain mountain inspector at Heriot-Watt University, and an environmental consultant in Aberdeen.

Finally, enthused by attending a workplace first aid course and fed up with low pay and a long commute, Walker decided it was time to do something else. "The course sowed the seed and as that seed grew the irritation with the commute grew as well," he recalls. "I thought "let's just go and do medicine."”

In 1995, at the age of 31, Walker enrolled at the Dundee University School of Medicine. Postgraduate students made up a third of his year and their experience was an advantage on the course. "It was handy having done another degree before," Walker says. "We felt sorry for the ones straight out of school because they took longer to get their heads around how it worked. The graduates found it easier to adapt to the system."

Initially Walker presumed his career choices would be limited because of his age. "I felt that I didn't have the luxury of thinking about things too much because I was older," he says. But on an ear, nose, and throat placement in Dundee, Walker was inspired by his consultants to pursue a career in their specialty. "They were both interesting and interested, and they made you a full part of things," he recalls.

Walker takes a similar approach to mentoring and likes to get people involved and take an interest in them. "It's important people feel they have a function, that they're important, and their opinions are important," he says. "If you appear interested, people will respond."

After graduating in 2000 Walker went on to complete his basic surgical training in Dundee and registrar posts in Glasgow. In 2010 he became a consultant at the same hospital in which he was born-the Victoria Hospital in Kirkcaldy, Fife.

A skill from his old life that Walker has found invaluable as the clinical lead of his department is project planning. "If you can plan ahead and look at running a department from a business planning point of view that really helps," he says. "Projects tend to drift in hospitals when we're all trying to do so much. Formally planning and scheduling them is good for focusing.”

Despite chronic understaffing over the past few years, Walker is proud of how his service has grown. "It's been a challenge having no staff but developing the service," he says. "We've not just survived-we're now one of the best performing teaching units, we've taken on a lot more operations, and we've built up quite nicely."

Walker encourages people who dislike their job to do something else but warns that working in business is not necessarily a better option. "I've seen the other side of the grass," he says. "It's different but it's not any greener."

\section{Nominated by Miles Bannister}

"A born and bred Fifer, Mr Walker is a fantastic trainer and mentor to surgical trainees and has made the unit here one of the most popular and valued. His manner with everyone is exceptional and has seen the department through a lot of difficulties.

"His charm and warmth have allowed an expansion in the work that the department does, keeping it afloat for the coming years. Without him, it would not be the successful, productive, and friendly place we have. "Mr Walker teaches us, by example, two important abilities that are often overlooked in surgical training: those of personal interaction and clinical leadership. We learn a lot each day working for him, probably the most important lesson being how to stay sane and effective in the face of the chaos that can be the norm of working in the NHS."

Miles Bannister is a consultant otolaryngologist 